\title{
The Consistency of Judicial Choice
}

\author{
Paul M. Collins, Jr. \\ Department of Political Science \\ University of Houston \\ Houston, TX 77204-3472 \\ pmcollins@uh.edu
}

\begin{abstract}
Despite the fact that judicial scholars have developed reasonably well-specified models of the voting behavior of U.S. Supreme Court justices, little attention has been paid to influences on the consistency of the choices justices make. Aside from the methodological problems associated with failure to account for heteroskedasticity with regard to the justices' voting behavior, I argue that variance in judicial choice is also of theoretical import. Simply put, by uncovering influences on the stability of judicial choice, a more complete understanding of judicial decision making is provided. I explore this possibility by developing a theoretical framework that uncovers influences on the consistency of judicial choice which are then subjected to empirical validation. I show that the stability of judicial decision making is affected by attitudinal and strategic factors, as well as the Court's informational environment.
\end{abstract}

Paper Prepared for Delivery at the $101^{\text {ST }}$ AnNual Meeting of the American Political SCIENCE Association, Washington, D.C., SEPTEMBER 1-4, 2005 
The pursuit of consistency is perhaps the driving force behind all decision making (Heider 1946). Yet, within the context of judicial politics, consistency is often elusive. ${ }^{1}$ Although confronted with identical argumentation, jurists on collegial courts routinely disagree as to how the law should be applied in any given case. ${ }^{2}$ With regard to the U.S. Supreme Court, this is perhaps no more evident than in the rise of nonunanimous decisions since the early twentieth century. Still, researchers seeking to explain the behavior of judicial decision makers are necessarily motivated by the search for consistency within the behavior of jurists. Indeed, the concept of consistency is a key aspect of all of science: it is predictability that guides the researcher towards his or her formulation of theories and hypotheses that later allow for generalization (Severin and Tankard 1997: 159).

Despite the pivotal role of consistency in understanding judicial behavior, few analyses explicitly deal with the concept. ${ }^{3}$ This is unfortunate, for both judicial scholars (e.g., Baum 1994) and Supreme Court justices (e.g., Scalia 1997) recognize the desire for consistency in judicial decision making. But, by focusing primarily on how different types of variables influence the ultimate decisions of jurists, we are, in effect, missing a large piece of the puzzle. A more complete understanding of judicial behavior is achieved through the supplementary understanding of the variability in judicial decision making. In other words, instead of only trying to determine whether some X causes $\Upsilon$, a full understanding of the choices jurists make can only be achieved if we also

\footnotetext{
${ }^{1}$ For example, the justices have yet to articulate a clear standard for the alteration of precedent (see, e.g., Justice Scalia, concurring, in Harper v. Virginia Department of Taxation, 509 U.S. 86, at 103 [1993]).

2 Similarly, trial court judges handling different cases touching the same legal concept regularly disagree as to the correct interpretation of the law.

${ }^{3}$ For examples of research dealing with variability in decision making on the Supreme Court, see, e.g., Brenner and Spaeth (1995) and Spaeth and Segal (1999), analyzing the justices' voting behavior in precedent setting cases and cases that challenge those precedents, Epstein et al. (1998), addressing preference change over time, and Zorn and Caldeira (2003), investigating bias in media based measures of Supreme Court preferences (discussed in detail below).
} 
seek to determine whether some $Z$ contributes to the variably in $\Upsilon{ }^{4}$ The purpose of this paper is to contribute to an understanding of variability in judicial behavior by analyzing the circumstances under which the decision making of U.S. Supreme Court justices is more and less consistent.

An understanding of the consistency of judicial choice is important in several regards. First, an appreciation of the factors that contribute to the stability of judicial decision making in the Court speaks directly to extant models of judicial decision making. For example, Segal and Spaeth (1993: 69) propose that Supreme Court justices are able to "further their policy goals because they lack electoral or political accountability, ambition for higher office, and comprise a court of last resort that controls its own jurisdiction." Though some may quibble with this characterization of the Court, we are unable to determine - save for a massive overhaul of the Court, itself - whether the attitudinal model would manifest itself with regard to the Court by taking away the justices' lack of accountably, ambition, or the fact the Court sits atop the apex of the judicial system. However, we can examine the attitudinal model in cases that reach the Court via mandatory appeal. If controlling its own agenda is central to the attitudinal model, we would expect that, for cases reaching the Court on mandatory appeal, the attitudinal model is attenuated, i.e., the justices' behavior is less consistent (in terms of attitudinal voting) in these mandatory appeals. As will be argued below, an understanding of the variance in judicial choice is equally applicable to judicial decision making based on strategic approaches.

Second, there exists an important methodological reason for examining variance in judicial decision making. Virtually all models of the justices' voting behavior utilize a dichotomous dependent variable (whether it be operationalized as reverse/affirm, liberal/conservative, or by some

\footnotetext{
4 To more clearly make this point, allow me to draw an analogy to grades. While the mean (median, mode) certainly reveals information regarding the standing of the class on some assignment, the standard deviation also reveals a great deal of information. If we focused only on some measure of central tendency we would greatly reduce our knowledge of student progress by obscuring underlying tendencies in the data that are revealed by the standard deviation (i.e., variance).
} 
other means) and, accordingly, utilize maximum likelihood techniques for statistical inference. But, if heteroskedasticity exists in a maximum likelihood model, it leads to inefficient estimates of the model's parameter values, as well as biased estimates of the standard errors of those coefficients (e.g., Greene 2000: 517-521). In other words, unlike OLS regression in which heteroskedasticity leads to efficient, but biased estimates, in ML estimation heteroskedasticity leads to estimates that are both inefficient and biased, clearly a concern worthy of consideration.

In short, for both theoretical and methodological reasons, an understanding of the constancy of judicial choice is important to a more complete understanding of judicial voting behavior. In the next section, I develop and formulate several hypotheses related to the variance in the justices' decision making. I then subject my hypotheses to empirical validation using data on the justices' voting behavior during the 1946-2001 terms. Following this, I present an interpretation and discussion of the findings. I close with a brief conclusion section discussing the relevance of this research, as well as where future research might head.

\section{VARIABILITY IN JUDICIAL DECISION MAKING}

This section addresses factors that are hypothesized to influence the consistency of the justices' voting behavior. These proposed determinants include attributes of the justices, cases, and the information environment surrounding each case. I treat each in turn.

\section{THE JUSTICES}

According to the attitudinal model of Supreme Court decision making, the justices' voting behavior is primarily motivated by their policy preferences (e.g., Segal and Spaeth 2002). Simply put, liberal justices vote liberally, while conservative justices vote conservatively. ${ }^{5}$ Clearly though, there exists substantial variability with regard to the extent of each justice's ideological extremism. What is

\footnotetext{
${ }^{5}$ Further, the attitudinal model assumes that preferences are stable over time. See, for example, Rohde and Spaeth (1976: 75), Segal and Spaeth (2002: 91), and Spaeth (1972: 65), characterizing attitudes as a relatively enduring set of beliefs.
} 
the systematic effect of these differences? Research in social psychology tells us that - not surprisingly - decision makers with more extreme ideologies exhibit decreased variance in their behavior $^{6}$ and that extreme attitudes are better predictors of behavior than more moderate ideologies (e.g., Krosnick and Petty 1995; Wicker 1969; see also Miller and Peterson 2004). To more clearly see this point with regard to the Court, consider moderate justices. The attitudinal model's prediction for moderates at the level of the individual vote is functionally equivalent to saying a moderate's voting behavior is unstable; that is, a moderate justice will not consistently cast either liberal or conservative votes. ${ }^{7}$ Rather, he or she will vote conservatively in any given case with the same probability of voting liberally. However, the attitudinal model predicts that justices with more extreme ideologies - be they liberal or conservative - will exhibit more consistent behavior. In other words, compared to a moderate justice, such as O'Connor, an extremely conservative justice, such as Scalia, should exhibit more consistent voting behavior (i.e., decreased error variance). Further, research by Rosenberg (1968) reveals that decision makers with relatively extreme attitudes are resistant to attempts at persuasion. This is particularly applicable to the Court, given the adversarial nature of the American legal system in which the justices are continually facing persuasion attempts. Accordingly, the expectation is that justices with extreme ideologies will display more stable voting behavior.

Just as ideological extremism might reduce the variability in the justices' voting behavior, so too might the salience of the issue for a justice. Known as attitude importance, this concept was perhaps most notably applied to political science in Repass' (1971) study of voters in the electorate. Following Converse's (1964) failure to find widespread evidence of issue voting, Repass argued that

\footnotetext{
${ }^{6}$ Indeed, it is this principle that underlies the notion that decision makers, including Supreme Court justices (e.g., Segal and Spaeth 2002: 433), engage in motivated reasoning: examining empirical evidence and/or argumentation in a biased manner (e.g., Lord, Ross, and Lepper 1979).

7 This is the case because judicial scholars do not, as of yet, trichotomize votes into liberal, moderate, and conservative.
} 
researchers might be best suited by focusing on those issues most relevant to the survey respondent (Miller and Peterson 2004: 851). Within the field of judicial politics, several studies suggest that a justice's attitudes operate particularly strongly in cases that are salient to that justice (Bartels 2005; Segal 1986: 939; Spaeth and Segal 1999: 309-311; Unah and Hancock 2003). Cases that are salient to a justice stand out on the Court's docket and are thus accorded a disproportionate amount of attention by that justice. This results in that justice asking more questions during oral argument, pressing for greater clarity on issues (Unah and Hancock 2003; see also Epstein and Knight 1998: 74; Schubert, Peterson, Schubert, and Wasby 1992). In short, when a justice attaches personal importance to an issue, the expectation is that he or she will become more cognitively engaged in that issue, leading to more stable voting behavior. To be sure, there is no theoretical reason to expect issue salience to directly contribute to the directionality of an individual justice's voting behavior. Instead, issue importance should drive the consistency of that behavior. Accordingly, the expectation is that a justices' voting behavior will be more consistent in cases that are salient to that justice.

Finally, a justice's length of service on the Court might influence the consistency of his or her voting behavior. Past research dealing with the justices' merits votes to validate acclimation effects has utilized one of two methodological strategies. First, several studies compare the voting behavior of new justices to their more experienced brethren (e.g., Brenner 1983; Heck and Hall 1981; Snyder 1958). However, this methodology is unable to provide evidence as to whether individual justices experience acclimation effects as a comparison between justices (one new to the bench, one more senior) does not establish variability over the length of a particular justice's tenure on the bench. A second line of research examines acclimation effects by comparing the voting behavior of individual justices during their first terms on the Court to later in their careers (e.g., Hagle 1993; Pacelle and Pauly 1996). By essentially "making each justice his or her own control" 
(Hagle 1993: 1144), this strategy is able to provide evidence for or against acclimation effects for individual justices. However, the approach is nonetheless problematic as it implicitly hypothesizes directional differences in a justice's voting behavior manifest themselves over time. In other words, evidence of an acclimation effect is said to exist if, for example, we find that Warren voted conservatively $44 \%$ of the time in his first two years on the Court, compared to $32 \%$ for the remainder of his career on the bench (Hagle 1993). But, this strategy can miss important evidence of instability. For example, if Warren voted conservatively $42 \%$ of the time during his first term on the Court and 22\% in his second term, no evidence for an acclimation effect would be provided (as the comparison of Warren's behavior during his first two terms would be identical to the remainder of his career: $32 \%$ liberal votes cast). ${ }^{8}$ Clearly, however, Warren's voting behavior during his first two terms in this hypothetical example is variable and this instability is exactly consistent with the claim of initial disorientation in the acclimation literature. In this sense, acclimation effects are not about directionality, but instead about instability. Examining the error variance in a justice's voting behavior offers perhaps the most appropriate manner to test for acclimation effects. If acclimation effects exist for Supreme Court justices, the expectation is that the variance in a justice's voting behavior will decrease as his or her tenure on the Court increases. ${ }^{9}$

\section{THe CASES}

In addition to attributes of the justices, one case specific factor might also influence the variance in the justices' decision making. Namely, I expect that cases arriving at the Court on a grant of a writ of certiorari will be better vehicles for the application of the justices' policy

\footnotetext{
${ }^{8}$ In point of fact, Warren voted conservatively $46 \%$ of the time during his first term on the Court and $29 \%$ during his second term.

${ }^{9}$ Further, using the heteroskedastic probit model to test for acclimation effects is particularly useful as it does not assume that the error variance in a justice's voting behavior is linear over the course of a justice's career, nor does it require a researcher to establish a somewhat arbitrary cutpoint as to when a justice has "fully acclimated" (for example, periods tested in existing research range from one to five years).
} 
preferences, as compared to cases arriving at the Court as a result of its mandatory jurisdiction, thereby reducing the variance in the justices' decision making. ${ }^{10}$ As mentioned above, control over the Court's docket is one of the primary explanations for why the justices are able to vote their preferences on the Court (Segal and Spaeth 2002). The justices have the discretion to pick-andchoose their certiorari cases, but do not have such complete control over the cases they hear under the Court's mandatory jurisdiction. ${ }^{11}$ In selecting cases to hear under their discretionary jurisdiction, the justices tend to decline to hear cases that have "bad facts" - those cases where the Court's decision is likely to be more fact-based than policy-based (Perry 1991: 234-236). From the attitudinal perspective, the justices decline to hear such cases because they limit the ability of the justices to maximize the application of their policy preferences. Thus, cases granted writs of certiorari are likely to be those cases in which the issues before the Court are clearly presented and which surprises seldom manifest themselves. Conversely, the justices have diminished control over the types of cases they hear under their mandatory jurisdiction. Such cases are more likely than discretionary cases to include complications that limit the ability of the justices to employ their policy preferences. Instead, these cases might be decided on the narrowest factual grounds possible. For example, if a procedural issue arises during the decision process, it is likely that the justices will never reach the main issue in the case (Perry 1991: 234), which limits the ability of the justices to

${ }^{10}$ Cases reaching the Court as a result of its mandatory jurisdiction arrive either under its original jurisdiction (which typically include disputes between two states or controversies involving ambassadors or other foreign diplomats) or under its appellate jurisdiction (which include cases that Congress designates as mandatory). In 1988, Congress practically eliminated virtually all of the Court's mandatory jurisdiction, with the exception of those cases that come from three-judge district courts that Congress designates as necessary to resolve complex statutory problems (Stern et al. 2002: 69). During the 1946-2001 terms, 80 percent of the Court's cases arrived via a writ of certiorari ( 75 percent before the 1988 rule change, 95 percent after). The cases arriving at the Court via mandatory appeal are generally reflective of the Court's docket as a whole: civil rights and liberties cases make up 52\%, unions and economic activity $25 \%$, with the remainder consisting of judicial power (13\%), federalism (4\%), federal taxation (5\%), and interstate relations and miscellaneous $(1 \%)$ cases.

11 The notion that cases "on appeal" must be heard is a misnomer. While the justices do take a significant number of cases on appeal they would not hear if the case arrived via a certiorari petition, they do not hear all of the cases that reach the Court under its mandatory jurisdiction as they have the ability to dismiss those undesirable cases that arrive "on appeal" for lack of a substantial federal question (Perry 1991: 104-105). 
decide the case in-line with their policy preferences. Under their discretionary jurisdiction, the justices can avoid such cases altogether; under their mandatory jurisdiction they are compelled to hear such dismal cases. ${ }^{12}$ Accordingly, the expectation is that the justices' voting behavior will be more stable for cases arriving at the Court as a result of granting writs of certiorari than cases arriving under the Court's mandatory jurisdiction.

\section{THE INFORMATIONAL ENVIRONMENT}

Finally, two aspects of the informational environment at the Court are expected to influence the consistency of the justices' voting behavior. First, I expect that relatively high levels of interest group amicus curiae ${ }^{13}$ involvement will increase the variance in the justices' decision making. In cases without amicus participation, there are essentially two perspectives for the justices to consider (those of the petitioner and respondent). However, when amicus briefs are present in a case, the justices are the recipients of information that alters the informational environment at the Court by expanding the scope of the conflict (e.g., Schattschneider 1960). By raising new issues in the Court, amicus briefs confound already uncertain decisions the justices make regarding the application of the law in a case. This uncertainty is argued to lead to more variable behavior. In cases without amicus participation, the scope of the conflict is narrow and the justices generally only consider issues raised by the litigants (e.g., Epstein, Segal, and Johnson 1996). In cases with amicus participation, the

12 For example, in Rockford Life Insurance v. Illinois Department of Revenue (1986), Justice Stevens made the following comments: "The issue presented is not the type that would usually merit our attention if presented in a petition for certiorari. The issue has divided neither the federal courts of appeals nor the state courts. Indeed, aside from the Illinois courts, no court has ever considered whether Ginnie Maes are exempt from state taxes. Nor does it appear that this case presents an overly important question of federal law 'which has not been, but should be, settled by this Court.' This Court's Rule 17.1(c). The fact is that the Illinois property tax imposed here was repealed in 1979. Nonetheless, this case arises under our mandatory jurisdiction, $28 \mathrm{U}$. S. C. $\int 1257(2)$, and Congress has not allowed us to consider these factors in deciding whether to rule on this case on its merits" (482 U.S. 182, at 184).

13 Amicus curiae is literally the Latin for "friend of the court." Amicus curiae briefs are legal briefs filed by entities other than the direct parties to litigation that frequently speak to legal, policy, and separation of powers issues not addressed by the direct parties to litigation. Despite the fact that their name implies neutrality, these briefs are, in fact, adversarial in nature, almost always advocating for a particular disposition in the Court. 
scope of the conflict is broad because the amici bring new issues to the justices' attention. By introducing issues or expanding on issues the direct litigants were only able to make in abbreviated form, amici make it difficult for the justices to determine what the correct application of the law is in each case. Further, recent research indicates that amicus briefs have a significant impact on the justices' decision making (Collins 2004a; Kearney and Merrill 2000; but see Songer and Sheehan 1993) and that this influence is not dependant upon the congruence of the information in the brief with the policy preferences of the justices (Collins 2005). By influencing judicial decision making regardless of whether the justices are predisposed to agree with the information presented in the briefs - amicus briefs serve to attenuate the justices' attitudinal voting behavior. By inducing the justices to cast votes that are not necessarily consistent with their policy preferences, amicus briefs can serve to decrease the consistency of expected attitudinal behavior. Accordingly, the expectation is that the justices voting behavior will be less consistent in cases attracting a relatively large amount of amicus curiae participation. ${ }^{14}$

Second, I expect that, as the tenure of a natural Court - a period of the Court that exhibits no membership change - increases, the justices' voting behavior will become more consistent. With each case decided by a natural court, the justices have an enhanced ability to predict the likely positions of the other justices. This is important because Court decisions are, of course, the result

14 One might argue that this hypothesis is only applicable to cases in which the justices receive amicus briefs supporting both parties to a case. However, this is not necessarily the case. The scope of the conflict is often expanded even in those cases in which amicus briefs are filed supporting only one litigant because those briefs draw the justices' attention to issues not addressed by the litigants, therefore altering the informational environment surrounding the case. For example, in NAACP v. Claiborne (1982), a case involving whether participants in a boycott can be held liable for damages to a business that incurred through non-violent means, three amicus briefs were filed for the petitioner and none were filed for the respondent. In its brief, the AFL-CIO addressed whether an organization can be held liable for the criminal misconduct of its members, arguing that the imputed liability doctrine in commerce does not apply to political boycotts. The ACLU focused on the free expression issue in the case, arguing for an expansive interpretation of the First Amendment that encompasses economic boycotts. The American Jewish Congress spotlighted the conspiracy issue in the case, in addition to providing a detailed discussion as to the perceived illegality of the lower court's ruling on damages. As this case makes clear, even amici supporting only one litigant have the potential to influence the justices' decision making by raising new issues and reframing arguments already presented by the parties. 
of bargaining among justices (Maltzman, Spriggs, and Wahlbeck 2000: Murphy 1964). Drawing on intuitions from strategic characterizations of the Court, Merrill (2003:573) notes that as the length of a natural court increases, the justices will make fewer mistakes in the predicting the positions of the other justices. If a justice is better able to predict the positions of her fellow justices, she can better realize the application of her own policy preferences in the case due to her improved ability to figure out how far her fellow brethren are willing to move on an issue. In this sense, with each case decided by a natural Court, a justice updates her probability estimates of the preferences of her fellow justices, allowing her to determine exactly where - spatially speaking - her fellow justices are willing to move to obtain a winning coalition in-line with her policy preferences. Simply put, if a justice can better realize the likely positions of her colleagues, this can increase her ability to determine how her own policy preferences dictate voting. In addition, Merrill notes that, as the length of a natural Court increases, the justices are increasingly likely to engage in cooperation, which in turn should make their decision making more stable than during a period of the Court with rampant membership change. To put it differently, compared to a Court in flux (i.e., one exhibiting great membership change), a justice on a Court in stasis (i.e., one exhibiting no membership change) has greater information regarding the preferences of her fellow justices, which implies that she will make fewer mistakes in realizing the application of her own policy preferences due to her improved certainty resulting from the lack of membership change on the Court. ${ }^{15}$ The expectation is that a justices voting behavior will become more stable as the duration of a natural Court increases.

\section{DATA AND METHODOLOGY}

In order to test the validity of the proposed hypotheses, I examine the justices' voting behavior in all orally argued cases decided during the 1946-2001 terms, using the justice-vote as the

\footnotetext{
15 In game theoretic terms, justices on a natural Court are participants in a repeated game, with cooperation developing over time (e.g., Axelrod 1984).
} 
unit of analysis. ${ }^{16}$ While I am primarily interested in evaluating influences on the constancy of the justices' voting behavior (i.e., the error variance), it is necessary to control for factors that influence the ultimate choices justices make (i.e., the liberal or conservative nature of the justices' votes). Accordingly, I use heteroskedastic probit (e.g., Alvarez and Brehm 2002), which simultaneously estimates the effect of independent variables on both the mean and variance of a binary dependent variable by relaxing the assumption that the variance is equal to one (as in a homoskedastic probit model) and, instead, allowing the variance to alter with respect to predictor variables. To control for the non-independence of observations - the fact that there are approximately nine observations for each case in the data - the model is estimated using robust standard errors, clustered on case citation. This enables the model to account for this and limits the effects of model misspecification (e.g., Giles and Zorn 2000: 13; King 1998: 34).

The dependant variable captures the ideological direction of the individual justice's voting behavior, as identified in the Spaeth $(2002,2003)$ databases, and is scored 1 for a liberal vote and 0 for a conservative vote. To account for factors that influence the justices' choices (i.e., the mean vector), I include several controls. To measure the justices' Attitudes, I employ the Segal and Cover (1989) scores, as updated by Segal et al. (1995), which are based on editorial commentary appearing in newspapers regarding the justices' policy preferences made between their presidential nomination and Senate confirmation. ${ }^{17}$ This variable ranges from -1.0 (extremely conservative) to +1.0 (extremely liberal). The expected sign of this variable is positive, indicating that justices with liberal

16 These data were obtained primarily through the Spaeth $(2002,2003)$ databases, with exceptions discussed below. Relevant votes were selected using the case citation plus split vote as the unit of analysis.

17 Although the Segal and Cover scores provide a valid and reliable indicator of judicial preferences, while avoiding the circularity problem that plagues other measures, the newspaper editorials from which these scores are based "deal almost exclusively with support by the justices for civil liberties and civil rights" (Segal and Cover 1989: 561). As such, their application beyond civil rights and civil liberties law is perhaps inappropriate (Epstein and Mershon 1996). Accordingly, a separate analysis was performed considering only civil rights and liberties cases. None of the results decidedly altered. 
policy preferences are more likely than conservative justices to cast liberal votes. To control for the Court's well known practice of accepting cases on appeal it seeks to reverse (Perry 1991; Schubert 1959; Segal and Spaeth 1993), I include a variable labeled Lower Court Direction, coded 1 if the decision of the lower court the Supreme Court is reviewing was liberal in direction and 0 if it was conservative. The expected sign of this variable is negative, indicating that a justice is more likely to vote conservatively given that the lower court handed down a liberal decision. To control for the import of party resources in judicial decision making (Galanter 1974; Sheehan, Mishler, and Songer 1992), I utilize two variables: Liberal Litigant Resources and Conservative Litigant Resources. These are based on the status continuum of litigants adopted generally from Sheehan et al. ([1992]; see also Collins 2004a; McGuire 1995, 1998). That is, I ranked litigants, according to increasing resources, as follows: poor individuals $=1$, minorities $=2$, individuals $=3$, unions $/$ interest groups $=4$, small businesses $=5$, businesses $=6$, corporations $=7$, local governments $=8$, state governments $=9$, and the federal government $=10{ }^{18}$ It is expected that the sign of the Liberal Litigant Resources variable will be positive, indicating that a justice is more likely to vote liberally when an highresource litigant advocates that position. Conversely, it is expected that the Conservative Litigant Resources variable will be negative in direction, indicating that a justice is more likely to vote conservatively when a highly-capable litigant advocates the conservative position. Finally, four variables are included to account for the influence of amicus curiae participation on the justices' voting behavior (e.g., Collins 2004a, 2005; Kearney and Merrill 2000). ${ }^{19}$ Liberal Amicus Briefs and Conservative Amicus Briefs represent the number of liberal and conservative amicus briefs filed in each

\footnotetext{
${ }^{18}$ See Sheehan et al. (1992) for the inclusion of litigants in these categories. In addition, I have coded litigants as fitting into an interest group category. This includes all litigants identified in the Spaeth databases as the American Medical Association, political action committees, unions, union members, and environmental organizations.

19 The data on amicus curiae participation come from the Kearney and Merrill (2000) amicus curiae database for the 1946-1995 terms and were collected by the author for the remaining terms.
} 
case. The expectation is that, as the number of liberal (conservative) amicus briefs increases, so too will the likelihood of observing a liberal (conservative) vote. To control for the influence of the Solicitor General (SG) as amicus curiae (e.g., Bailey, Kamoie, and Maltzman 2005; Deen, Ignagni, and Meernik 2003; O’Connor 1983), two variables are used: SG Liberal Amicus and SG Conservative Amicus. These variables are scored 1 if the SG filed an amicus brief arguing the liberal or conservative position, respectively, and 0 otherwise. The expectation is that a justice will cast a vote in-line with the position advocated by the SG.

I now turn to a discussion of the operationalization of the variables expected to influence the consistency of the justices' voting behavior, that is, those factors that effect the error variance in the dichotomous choice part of the model. To measure the individual justice's Ideological Extremism, I simply square each justice's Segal and Cover score. Higher scores on this variable reflect more extreme ideologies. Therefore, the expected sign of this variable is negative, indicating that justices with more extreme ideologies will exhibit more consistent voting behavior, as compared to their more moderate counterparts. In order to capture the Issue Salience of a case to the individual justice, I create a variable that counts the number of separate opinions each justice wrote prior to the case at hand in each of the issues areas identified in the Spaeth $(2002,2003)$ databases. Majority opinions were excluded from consideration because they may be assigned to a justice regardless of whether the issue area is important to that justices; instead the most predominant force affecting opinion assignments relates to a justice's ideological proximity to the chief justice or most senior justice in the winning coalition (Brenner 1990). Those dissenting and concurring opinions that a justice joined (as opposed to wrote) are excluded because the former behavior constitutes less of a public commitment to the development of law within an issue area than writing the opinion oneself (e.g., Collins 2004b). The expected sign of this variable is negative, indicating that justices will exhibit 
more consistent voting behavior in cases that are salient to them. ${ }^{20}$ To capture the possibility that a justice's voting behavior will become more stable over time, I include a variable labeled Tenure that is a simple count of each justice's length of service on the Court. The expected sign of this variable is negative, revealing a decrease in variability as a justice's tenure on the Court increases. ${ }^{21}$ To capture whether the mechanism by which a case arrives at the Court influences the stability of the justices' decision making, I include a variable labeled Certiorari. This variable is scored 1 if the case arrived at the Court via its discretionary jurisdiction and 0 if it arrived by mandatory appeal. The expected sign of this variable is negative, indicating that the justices' voting behavior is less variant in discretionary than in mandatory cases. Two variables capture the informational environment at the Court. To account for the possibility that the justices' voting behavior is more variant in cases in which interest groups expand the scope of the conflict, a variable labeled Total Amicus Briefs is included. This variable represents the sum of the Liberal and Conservative Amicus Brief variables discussed above. The expected sign of this variable is positive, indicating that the justices' decision making will be more variable in cases attracting a relatively large number of amicus briefs. To capture the possibility that the justices' decision making becomes more stable as norms of cooperation develop on a natural Court, I include a variable labeled Prior Cases, which is simply the number of orally argued cases each natural court disposed of prior to the case at hand. The expected sign of this variable is negative,

20 This measure is particularly desirable because it is both contemporaneous (i.e., relevant to the justice at the time the case is being decided) and measures salience to the individual justice, not to, for example, newspaper editors or organized interests. In addition, it is generally consistent with approaches to measuring attitude importance that ask respondents to self-identify relevant issues to them (e.g., Krosnick 1988) in that the justices self-identify salient issues by making a public commitment to the development of the law through separate opinion writing. As Justice Ginsburg put it: "public accountability through the disclosure of votes and opinion authors puts the judge's conscience and reputation on the line" (1990: 140). Further, its operationalization is consistent with psychological research measuring attitudinal importance that stresses experience with an issue and the development of a vested interest with the issue (e.g., Prislin 1996).

${ }^{21}$ Caldeira and Zorn (2003) note that this technique also taps into whether the Segal and Cover scores, which are static, decay over the length of a justice's career (i.e., perform worse over time). If this variable is associated with measurement error with regard to the Segal and Cover scores, its expected sign is positive, indicating that increased error variance exists over time. 
indicating that, as the number of cases each natural Court disposed of increases, the justices will exhibit more consistent voting behavior.

Finally, following Zorn and Caldeira (2003), I include one additional control variable in the variance vector that accounts for measurement error in the justices' Segal and Cover scores. Specifically, I include a variable, Editorials, that is the number of editorials the Segal and Cover scores are based on. ${ }^{22}$ This accounts for the fact that the Segal and Cover scores are based on editorials regarding the justices that vary widely in number, from a low of two Justices Goldberg, Marshall, and Whittaker) to a high of 47 for Justice Thomas. Due to this, I hypothesize that scores derived from a large number of editorials incorporate more information and therefore should be more accurate than scores derived from less editorials. Accordingly, I expect that this variable will be negatively signed, indicating that justices whose ideologies are estimated using more information will exhibit less variance than justices whose ideologies are estimated using less information, due to the measurement error associated with these scores.

\section{RESULTS}

\section{*** TABLE 1 ABOUT HeRE ***}

Table 1 reports the results of the heteroskedastic probit model. Of import, note the model correctly predicts over $63 \%$ of votes for a percent reduction in error of over $20 \%$ and, more importantly, substantial evidence of heteroskedasticity exists in the data, which will be discussed in detail below.

Turning first to the choice model, all of the variables are correctly signed and achieve statistical significance. Consistent with the attitudinal model's predictions, the more liberal a justice's

22 Unfortunately, Segal, Epstein, Cameron, and Spaeth (1995) do not report the number of editorials from which Justices Ginsburg and Breyer's scores are derived. Accordingly, I use the mean number of editorials for the justices who sat on the same natural Court with Ginsburg and Breyer, excluding Thomas's score, who was an extreme outlier due to the media attention given to his nomination stemming from the Anita Hill scandal. 
policy preferences, the more likely that justice is to cast a liberal vote. In addition, the results indicate that, when the Supreme Court is reviewing a liberal decision, the justices are 15\% more likely to vote conservatively than when the Court is reviewing a conservative decision. ${ }^{23}$ With regard to litigant resources, the results affirm that, as a litigant moves up the resource continuum reported above, the justices are increasingly likely to support that litigant's position. For example, compared to an individual litigant, when the federal government argues the liberal position, this results in a $6 \%$ increase in the likelihood of observing a liberal vote. Finally, these results also reveal strong support for the role of amicus curiae briefs in shaping the justices' decision making. A one standard deviation change in the number of liberal amicus briefs (from one to three) results in a $4 \%$ increase in the likelihood of observing a liberal vote. Conversely, a one standard deviation change in the number of conservative briefs (from one to three) results in a 3\% decrease in the likelihood of observing a liberal vote. When the Solicitor General files a liberal amicus brief, a justice is $12 \%$ more likely to vote liberally; when the SG files a conservative brief, a justice is $10 \%$ less likely to cast a liberal vote.

Moving to the error variance part of the model, note that all of the variables are signed in the correct direction and achieve statistical significance. Beginning with attributes of the justices, several interesting findings are present. First, the results corroborate the argument that ideological extremism reduces the variability in a justice's decision making. In other words, compared to a more moderate justice, an extremely liberal (or conservative) justice engages in more consistent voting behavior. This, of course, should be expected, given the strong support for the attitudinal model provided in the choice part of the equation and has a fascinating implication. Namely, if extreme attitudes lead to more stable voting behavior, this suggests that factors that shape a moderate justice's decision calculi might be less consequential for more ideologically extreme justices. In this

\footnotetext{
${ }^{23}$ Marginal effects were calculated holding all other variables at their mean or modal values.
} 
sense, the voting behavior of moderate justices might be more context dependent (e.g., more reliant on specific aspects of a case) as compared to justices with extreme ideologies.

Second, just as the strength of a justice's attitude shapes his or her decision making, so too does the relevance of the issue for that justice. In cases involving those issue areas in which a justice authored a relatively large number of nonconsensual opinions - thus making a public commitment to the development of the law in those issue areas - that justice's behavior is less variable, as compared to issue areas in which the justice did not engage in separate opinion writing (i.e., those issues less salient to the justice). From the perspective of the attitudinal model, this finding suggests that ideology plays a central role in cases that are salient to a justice, reducing the chances of observing non-attitudinal behavior. Further, this finding corroborates research in social psychology that reveals that attitude-behavior consistency is enhanced when an individual has previous experience with the attitude object (e.g., Fazio and Zanna 1981).

Third, note that, as a justice's length of tenure on the Court increases, the variability in that justice's decision making decreases. This is interesting for two reasons. First, it provides clear evidence in support of an acclimation effect for Supreme Court justices: relative to their first terms on the Court, justices later in their careers exhibit more consistent voting behavior, suggesting that Supreme Court justices, like other jurists, undergo an acclimation period. ${ }^{24}$ Second, the results speak to the robustness of the Segal and Cover scores with respect to their longitudinal utility. Because the Segal and Cover scores are static measures of policy preferences taken before a justice's first vote on the Court, a plausible expectation is that the scores' capability of predicting votes should decrease

\footnotetext{
${ }^{24}$ The model was also run using the log of the Tenure variable reported in Table 1 . The results of that analysis also provide support for an acclimation effect for Supreme Court justices; that is, as a justice's length of tenure increases, his or her error variance decreases. None of the other variables were substantially altered by this alternative model specification.
} 
over time (e.g., Zorn and Caldeira 2003). ${ }^{25}$ If this was the case, we would expect the sign of this variable to be positive, demonstrating an increase in error variance over time (i.e., that the Segal and Cover scores perform worse over time). However, these results suggest just the opposite. Instead, they provide evidence that a single measure of the justices' attitudes might be capable of accurately predicting the justices' votes over their entire careers (see also Zorn and Caldeira 2003; but see Epstein et al. 1998).

\section{*** Figure 1 ABOUT HeRE ***}

The results also indicate that a justice's voting behavior is more stable in cases that arrive via certiorari than on mandatory appeal. This finding is of import as it suggests that the attitudinal model's strong predictive powers might be attenuated in cases the justices cannot choose for review. To more clearly see the effects of this, consider Figure 1, which plots predicted error variance by ideological extremism for both certiorari cases and mandatory appeals, holding all other variables at their mean or modal values. The horizontal axis reflects attitudinal extremism (the square of the Segal and Cover scores), while the vertical axis represents the predicted error variance. Consistent with Table 1, this figure illustrates that justices with more extreme ideologies exhibit decreased error variance. More importantly, however, note the relatively large variance in cases arriving at the Court through its mandatory jurisdiction, as compared to those arriving by granting certiorari. In plain terms, the justices voting behavior is clearly more erratic in mandatory appeals, suggesting, in part, that the attitudinal model's predictive capability is especially enhanced by the justices' ability to pick and choose cases for appeal.

The results also support my argument that the Court's information environment influences the justices' decision making. First, the findings provide support for my contention that the justices'

25 As Zorn and Caldeira (2003: 11-12) note, this might be due to preference changes that occur over time, the possibility that the issue areas on which the scores were based no longer play an prominent role on the Court's agenda (e.g., Pacelle 1991), or because of changes in how justices are judged to be liberal or conservative manifest themselves over time. 
voting behavior becomes more stable as norms of cooperation among the justices develop over time. This suggests that justices on the Court engage in a type of repeated game: with each case decided on a Court without membership change, a justice has greater information regarding the preferences of her fellow justices, which implies that she will make fewer mistakes in realizing the application of her own policy preferences due to her improved certainty with regard to her position relative to the other justices. Second, the results also speak to the important role organized interests play in the Court. As the number of amicus curiae briefs increases, so too does the variability in the justices' decision making. By presenting information that might otherwise be unavailable to the justices, interest groups are able to expand the scope of the conflict, making the justices' decision making more variant than in cases with no (or less) amicus participation. ${ }^{26}$

Finally, the control variable, Editorials, indicates that systematic measurement error exists in Segal and Cover's proxy for judicial ideology. Specifically, the results indicate that Segal and Cover scores that are based on a relatively large number of editorials provide a better measure of the justices' attitudes than those scores based on only a few editorials in the sense that the score's ability to account for a justice's voting record is enhanced (see also Zorn and Caldeira 2003). This suggests that accounting for the possibility of measurement error in these scores should be taken seriously by researchers: failure to do so may lead to inefficient estimates of a model's parameter values and result in biased estimates of the standard errors of those values.

\section{CONCLUSIONS}

The pursuit of consistency drives both judicial decision making and scholarly attempts to explain that decision making. Yet, few scholars have explicitly attempted to model the variance in the choices jurists make. This paper provides an initial foray into this line of research by examining

$26 \mathrm{I}$ also ran the model including variables in the variance vector that represented whether the Solicitor General filed an amicus brief and whether amicus briefs were filed on only one side of the case. Neither of those variables achieved statistical significance, while all of the other variables retained their significance. 
factors that influence the consistency of judicial choice on the U.S. Supreme Court. I demonstrate that attributes of the justices, the cases, and the informational environment surrounding each case all contribute to the stability of judicial voting behavior. I find that judicial voting behavior is especially stable in cases that are salient to the individual justice and that stability increases over time, the latter providing evidence for acclimation effects for Supreme Court justices. Further, my results show that two factors implicating the attitudinal model also effect the variability in voting behavior. Specifically, my findings indicate that justices with extreme ideologies exhibit more stable voting behavior as compared to their more moderate counterparts and that the justices' decision making is less consistent in cases arriving via mandatory appeals (as opposed to certiorari grants), suggesting the attitudinal model is especially applicable to ideologically extreme justices and attenuated in cases that reach the Court's agenda by Congressional mandate. In addition to offering leverage over the attitudinal nature of judicial decision making, my results also provide evidence that the justices' voting behavior is stabilized by norms of cooperation that develop over time and among the justices, therefore supporting strategic accounts of collegial decision making. Finally, I provide evidence that organized interest amicus curiae participation alters the information environment in the Court by confounding already uncertain choices, resulting in less consistent voting behavior in the part of the justices.

This research contributes to literature on judicial decision making in a number of ways. First, it is important because it offers additional leverage over the explanatory power of the attitudinal model. Instead of focusing solely on whether judicial attitudes influence judicial decision making, this research provides evidence as to under what circumstances ideology structures the choices justices make. Second, this research suggests that decision making on the Supreme Court is best explained through a number of approaches. While empirical support for the attitudinal model is strong, ideology does not contribute to every justice's decision in every case. Instead, the justices' 
decision making is influenced by strategic considerations (norms of cooperation that develop over time), as well as justice-specific attributes, such as a justice's length of tenure on the Court. With regard to the latter, acclimation effects, this research moves beyond previous studies by utilizing a particularly rigorous and suitable methodology for detecting acclimation effects. Finally, by explicitly modeling the error variance in judicial decision making, this research offers a more complete understanding of voting behavior on the U.S. Supreme Court. ${ }^{27}$ Additional pursuits along this line of inquiry might consider how modeling error variance applies to separation of powers and legal models of the Court. Because separation of powers models of choice make rather demanding assumptions about the justices (necessitating, for example, that the justices have knowledge of congressional indifference points), examining the influence of Congress on the Court might benefit from the study of variability in judicial decision making. In so doing, researches can provide rigorous tests of the theory, without necessarily making such demanding assumptions on the justices. For example, it is plausible that the influence of Congress on the Court does not deterministically influence the directionality of a justices' voting behavior, but instead the consistency of that behavior. Similarly, researchers examining the influence of precedent or jurisprudential regimes might benefit from an analysis of variability. Assuming jurisprudential regimes shape the justices' decision making, we might expect to see a decrease in error variance after the establishment of some regime. By understanding and analyzing the consistency of judicial choice, much can be learned about the voting behavior of judicial decision makers.

\footnotetext{
${ }^{27}$ It is important to note that the heteroskedastic probit model may not be suitable for all analyses of variance in judicial decision making. In particular, the model has poor small-sample estimation properties. For example, Keele and Park (2004), using Monte Carlo analysis, show that the heteroskedastic model is optimal only when there are at least 1,000 observations for two variables in each of the choice and variance vectors; when more variables are included in the model, the sample size must increase accordingly to achieve its desired estimation properties. Recall the present analysis contains over 57,000 votes, well exceeding Keele and Park's recommendations.
} 


\section{REFERENCES}

Alvarez, R. Michael, and John Brehm. 2002. Hard Choices, Easy Answers. Princeton: Princeton University Press.

Axelrod, Robert. 1984. The Evolution of Cooperation. New York: Basic Books.

Bailey, Michael, Brian Kamoie, and Forrest Maltzman. 2005. "Signals from the Tenth Justice: The Political Role of the Solicitor General in Supreme Court Decision Making." American Journal of Political Science 49: 72-85.

Bartels, Brandon L. 2005. "Heterogeneity in Supreme Court Decision-Making: How Case-Level Factors Alter Preference Based Behavior." Paper presented at the Political Methodology Summer Conference, Tallahassee.

Baum, Lawrence. 1994. “What Judges Want: Judges' Goals and Judicial Behavior.” Political Research Quarterly 47: 749-68.

Brenner, Saul. 1983. "Another Look at Freshman Indecisiveness on the United States Supreme Court." Polity 16: 320-28.

. 1990. "Measuring Policy Leadership on the United States Supreme Court: A Focus on Majority Opinion Authorship." In Studies in U.S. Supreme Court Bebavior. Harold J. Spaeth and Saul Brenner. eds. New York: Garland.

Brenner, Saul, and Harold J. Spaeth. 1995. Stare Indecisis. Cambridge: Cambridge University Press.

Collins, Paul M., Jr. 2004a. "Friends of the Court: Examining the Influence of Amicus Curiae Participation in U.S. Supreme Court Litigation." Law and Society Review 38: 807-32.

. 2004b. "Variable Voting Behavior on the Supreme Court: A Preliminary Analysis and Research Framework." Justice System Journal 25: 57-74.

. 2005. Friends of the Supreme Court: Examining the Influence of Interest Groups in the U.S. Supreme Court, 1946-2001. Ph.D. diss. Binghamton University.

Converse, Phillip E. 1964. "The Nature of Belief Systems in Mass Publics.” In Ideology and Discontent. David P. Apter. ed. New York: Free Press.

Deen, Rebecca E., Joseph Ignagni, and James Meernik. 2003. "The Solicitor General as Amicus, 1953-2000: How Influential?" Judicature 87: 60-71.

Epstein, Lee, Valerie Hoekstra, Jeffrey A. Segal, and Harold J. Spaeth. 1998. "Do Political Preferences Change? A Longitudinal Study of U.S. Supreme Court Justices.” Journal of Politics 60: 801-18.

Epstein, Lee, and Jack Knight. 1998. The Choices Justices Make. Washington: CQ Press. 
Epstein, Lee, and Carol Mershon. 1996. "Measuring Political Preferences." American Journal of Political Science 40: 261-94.

Epstein, Lee, Jeffrey A. Segal, and Timothy R. Johnson. 1996. "The Claim of Issue Creation on the U.S. Supreme Court." American Political Science Review 34: 845-52.

Fazio, Russell H., and Mark P. Zanna. 1981. "Direct Experience and Attitude-Behavior Consistency." In Advances in Experimental Psychology. Leonard Berkowitz. ed. New York: Academic Press.

Galanter, Marc. 1974. 'Why the 'Haves' Come Out Ahead: Speculations on the Limits of Legal Change." Law and Society Review 9: 95-160.

Giles, Michael W., and Christopher Zorn. 2000. "Gibson Versus Case-Based Approaches: Concurring in Part, Dissenting in Part." Law and Courts 10: 10-16.

Ginsburg, Ruth Bader. 1990. "Remarks on Writing Separately.” Washington Law Review 65: 133-50.

Greene, William H. 2000. Econometric Analysis. $4^{\text {th }}$ Edition. Upper Saddle River: Prentice Hall.

Hagle, Timothy M. 1993. “"Freshman Effects' for Supreme Court Justices.” American Journal of Political Science 37: 1142-57.

Harper v. Virginia Department of Taxation, 509 U.S. 86 (1993).

Heck, Edward V. and Melinda Gann Hall. 1981. "Bloc Voting and The Freshman Justice Revisited." Journal of Politics 43: 852-60.

Heider, Fritz. 1946. “Attitudes and Cognitive Organization.” Journal of Psychology 21: 107-112.

Kearney, Joseph D., and Thomas W. Merrill. 2000. "The Influence of Amicus Curiae Briefs on the Supreme Court." University of Pennsylvania Law Review 148: 743- 855.

Keele, Luke, and David K. Park. 2004. "Difficult Choices: An Evaluation of Heterogeneous Choice Models." Paper presented at the annual meeting of the American Political Science Association, Chicago.

King, Gary. 1998. Unifying Political Methodology: The Likelihood Theory of Statistical Inference. Ann Arbor: The University of Michigan Press.

Krosnick, Jon A. 1988. "The Role of Attitude Importance in Social Evaluation: A Study of Policy Preferences, Presidential Candidate Evaluations, and Voting Behavior." Journal of Personality and Social Psychology 55: 196-210.

Krosnick, Jon A., and Richard E. Petty. 1995. "Attitude Strength: An Overview." In Attitude Strength: Antecedents and Consequences. Richard E. Petty and Jon A. Krosnick. eds. Mahwah, New Jersey: Lawrence Erlbaum Associates. 
Lord, Charles G., Lee Ross, and Mark R. Lepper. 1979. "Biased Assimilation and Attitude Polarization: The Effects of Prior Theories on Subsequently Considered Evidence." Journal of Personality and Social Psychology 37: 2098-2109.

Maltzman, Forrest, James F. Spriggs, and Paul J. Wahlbeck. 2000. Crafting Law on the Supreme Court. Cambridge: Cambridge University Press.

McGuire, Kevin T. 1995. "Repeat Players in the Supreme Court: The Role of Experienced Lawyers in Litigation Success." Journal of Politics 57: 187-96. . 1998. "Explaining Executive Success in the U.S. Supreme Court." Political Research Quarterly 51: 505-526.

Merrill, Thomas M. 2003. "The Making of the Second Rehnquist Court: A Preliminary Analysis." St. Louis University Law Journal 47: 569-658.

Miller, Joanne M., and David A. M. Peterson. 2004. "Theoretical and Empirical Implications of Attitude Strength." Journal of Politics 66: 847-67.

Murphy, Walter F. 1964. Elements of Judicial Strategy. Chicago: University of Chicago Press.

NAACP v. Claiborne, 458 U.S. 886 (1982).

O’Connor, Karen. 1983. “The Amicus Curiae Role of the U.S. Solicitor General in Supreme Court Litigation." Judicature 66: 256-64.

Pacelle, Richard. 1991. The Transformation of the Supreme Court's Agenda: From the New Deal to the Reagan Administration. Boulder: Westview Press.

Pacelle, Richard and Patricia Pauly. 1996. "The Freshman Effect Revisited: An Individual-Based Analysis." American Review of Politics 17: 1-22.

Perry, H.W. Jr. 1991. Deciding to Decide: Agenda Setting in the United States Supreme Court. Cambridge: Harvard University Press.

Prislin, Radmila. 1996. "Attitude Stability and Attitude Strength: One is Enough to Make it Stable." European Journal of Social Psychology 26: 447-77.

Repass, David E. 1971. "Issue Salience and Party Choice." American Political Science Review 65: 389400.

Rockford Life Insurance v. Illinois Department of Revenue, 482 U.S. 182 (1986).

Rohde, David W., and Harold J. Spaeth. 1976. Supreme Court Decision Making. San Francisco: W.H. Freeman.

Rosenberg, Milton J. 1968. "Hedonism, Inauthenticity, and Other Goads Toward Expansion of a Consistency Theory." In Theories of Cognitive Consistency: A Sourcebook. Robert P. Abelson, 
Elliot Aronson, William J. McGuire, Theodore M. Newcomb, Milton J. Rosenberg, and Percy H. Tannenbaum. eds. Chicago: Rand McNally.

Scalia, Antonin. 1997. A Matter of Interpretation: Federal Courts and the Law. Princeton: Princeton University Press.

Schattschneider, E.E. 1960. The Semisovereign People: A Realist's View of Democracy in America. New York: Holt, Rinehart, and Winston.

Schubert, Glendon. 1959. Quantitative Analysis of Judicial Behavior. Glencoe: Free Press.

Schubert, James N., Steven A. Peterson, Glendon Schubert, and Stephen Wasby. "Observing Supreme Court Oral Argument: A Biosocial Approach.” Politics and the Life Sciences 11:3551.

Segal, Jeffrey A. "Supreme Court Justices as Human Decision Makers: An Individual-Level Analysis of the Search and Seizure Cases." Journal of Politics 48: 938-55.

Segal, Jeffrey A., and Albert D. Cover. 1989. "Ideological Values and the Votes of U.S. Supreme Court Justices.” American Political Science Review 83: 557-65.

Segal, Jeffrey A., Lee Epstein, Charles M. Cameron, and Harold J. Spaeth. 1995. "Ideological Values and the Votes of Justices Revisited." Journal of Politics 57: 812-23.

Segal, Jeffrey A., and Harold J. Spaeth. 1993. The Supreme Court and the Attitudinal Model. Cambridge: Cambridge University Press. . 2002. The Supreme Court and the Attitudinal Model Revisited. Cambridge: Cambridge University Press.

Severin, Werner J., and James W. Tankard, Jr. 1997. Communication Theories: Origins, Methods, and Uses in the Mass Media. New York: Longman.

Sheehan, Reginald S., William Mishler, and Donald R. Songer. 1992. "Ideology, Status and the Differential Success of Direct Parties Before the Supreme Court." American Political Science Review 86: 464-71.

Snyder, Eloise. 1958. “The Supreme Court as a Small Group.” Social Forces 36: 232- 38.

Songer, Donald R., and Reginald S. Sheehan. 1993. "Interest Group Success in the Courts: Amicus Participation in the Supreme Court." Political Research Quarterly 46: 339-54.

Spaeth, Harold J. 1972. In Introduction to Supreme Court Decision Making: Revised Edition. New York: Chandler Publishing. . 2002. The Vinson-Warren Supreme Court Judicial Database, 1946-1968 Terms. East Lansing: Department of Political Science, Michigan State University. 
. 2003. The Original United States Supreme Court Database, 1953-2001 Terms. East Lansing:

Department of Political Science, Michigan State University.

Spaeth, Harold J., and Jeffrey A. Segal. 1999. Majority Rule or Minority Will. Cambridge: Cambridge University Press.

Stern, Robert L., Eugene Gressman, Stephen M. Shapiro, and Kenneth S. Geller. 2002.

Supreme Court Practice: For Practice in the Supreme Court of the United States. $8^{\text {th }}$ ed. Washington: Bureau of National Affairs.

Unah, Isaac, and Ange-Marie Hancock. 2003. "Supreme Court Decision Making, Case Salience, and the Attitudinal Model." University of North Carolina-Chapel Hill Typescript. On file with author.

Wicker, Allen W. 1969. "Attitudes versus Actions: The Relationship Between Verbal and Overt Behavioral Responses to Attitude Objects." Journal of Social Issues 25: 41-78.

Zorn, Christopher, and Gregory A. Caldeira. 2003. "Bias and Heterogeneity in a Media-Based Measure of Supreme Court Preferences." Paper presented at the Arleen Carlson Symposium on Judicial Decision Making, Minneapolis. 
Table 1. Heteroskedastic Probit Results

\begin{tabular}{cc}
\hline Predictor & Parameter \\
& Estimate \\
\hline
\end{tabular}

Choice Model

$\begin{array}{lc}\text { Attitudes } & .267(.021)^{* * *} \\ \text { Lower Court Direction } & -.240(.024)^{* * *} \\ \text { Liberal Litigant Resources } & .013(.003)^{* * *} \\ \text { Conservative Litigant Resources } & -.023(.004)^{* * *} \\ \text { Liberal Amicus Briefs } & .034(.007)^{* * *} \\ \text { Conservative Amicus Briefs } & -.019(.005)^{* * *} \\ \text { SG Liberal Amicus } & .213(.037)^{* * *} \\ \text { SG Conservative Amicus } & -.158(.033)^{* * *} \\ \text { Constant } & .241(.042)^{* * *}\end{array}$

$\underline{\text { Variance Model }}$

Ideological Extremism

$-.077(.042)^{*}$

Issue Salience

$-.007(.002)^{* *}$

Tenure

$-.006(.002)^{* *}$

Certiorari

$-.189(.062)^{* *}$

Total Amicus Briefs

$.028(.010)^{* *}$

Prior Cases

$-.0002(.0001)^{*}$

Editorials

$-.020(.002)^{* * *}$

\section{Model Diagnostics}

$\mathbf{N}$

57,333

Wald $\chi^{2}$

$167.3 * * *$

Wald Test $\left(\ln \sigma^{2}=0\right)$

$124.2^{* * *}$

$\%$ Correctly Predicted

63.1

$\%$ Reduction in Error

20.6

Numbers in parentheses indicate robust standard errors, clustered on case citation.

$* \mathrm{p}<.05 ;{ }^{* *} \mathrm{p}<.01 ; * * * \mathrm{p}<.001$ (one-tailed tests). 


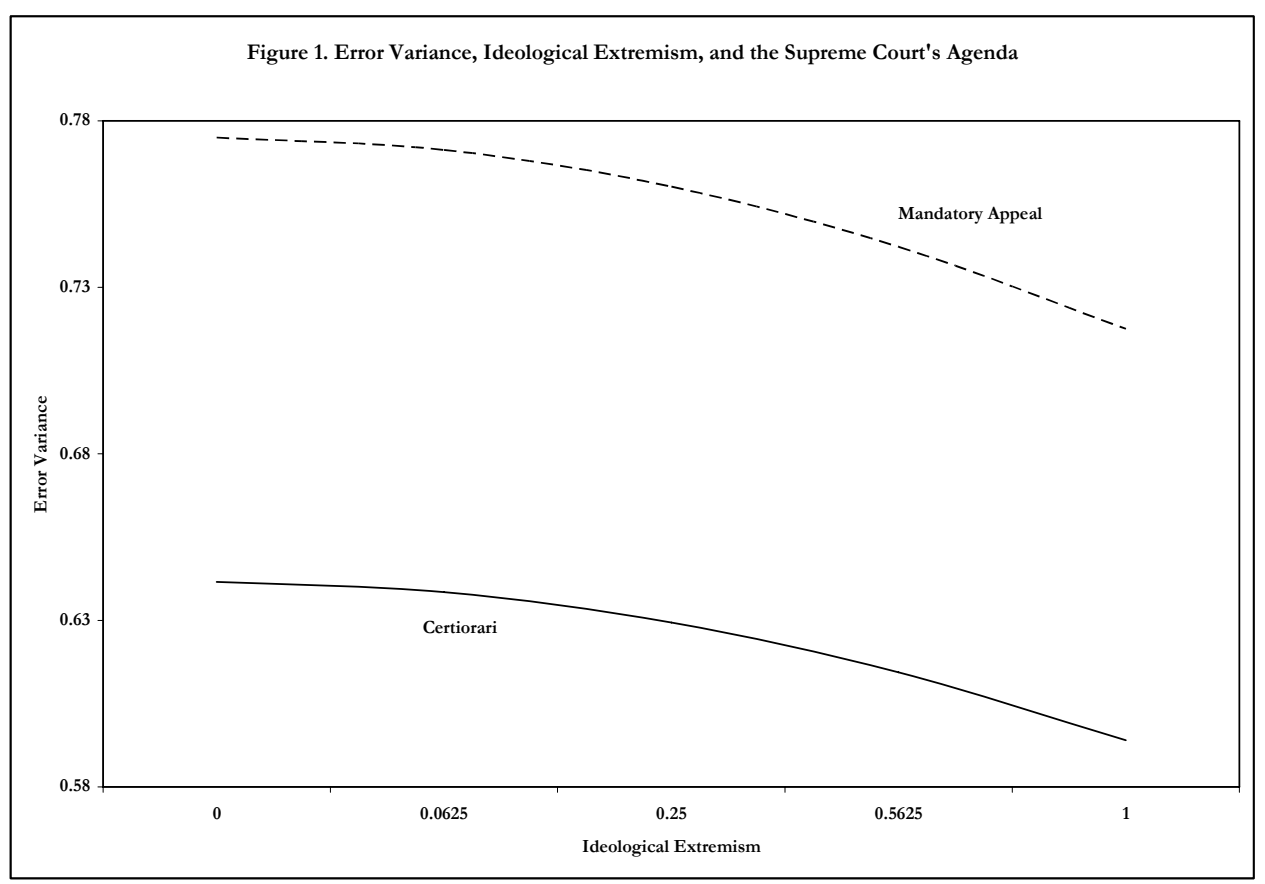

